\title{
The January 2014 Flashflood in the Ambato River (Catamarca, Argentina)- A Case Study of Megaboulders Fluvial Transport
}

DOI: $10.46932 / \mathrm{sfjdv2n2-153}$

Received in: March 1st, 2021

Accepted in: May 30th, 2021

\section{Moshe Inbar}

Department of Geography and Environmental Studies, University of Haifa,

E-mail: Israel.inbar@geo.haifa.ac.il

Julio A. Costello

Catedra de Geomorfologia, Universidad de Catamarca, Argentina.

E-mail: Jacoste2@hotmail.com

Jorge Eremchuk

Departamento de Geologia, Universidad de Catamarca, Argentina.

E-mail: inbar@geo.haifa.ac.il

\begin{abstract}
Megaboulders mantle the steep channels of mountainous rivers, and moderate incision rates by increasing channel roughness. Direct measurement of the transport of boulders in natural rivers is difficult, therefore there are few field studies on the subject. The transportation of megaboulders downslope in catastrophic floods in urban environments-_releases a destructive power. This study analyses the Ambato river flood that occurred in Argentina in January 2014 with an assumed recurrence interval of 1:100 years. The flood was caused by concentrated rainfall in the upper basin, at an elevation of $4000 \mathrm{~m}$.

The Ambato river forms a boulder alluvial fan drained by episodic floods. The 2014 flood caused casualties and economic losses in the village of El Rodeo in the province of Catamarca. Several houses and a bridge were destroyed and vehicles were swept away. All bedload sizes- including megaboulders with $2000 \mathrm{~mm}$ b-axis- were transported during the flood. The empirical equation for stream power value and the unit bedload transport rate of megaboulders were validated.

An assessment of boulder mobility is necessary to mitigate flow hazards in mountainous urban areas. The effects of climate change in semi-arid environments would be greater if they involved increased precipitation or more extreme rainstorms due to events such as El Nino.
\end{abstract}

Keywords: Flash floods, Boulder transport, Stream power, Ambato river, Flood victims

\section{INTRODUCTION}

Analysis of bedload transport is useful for channel morphology engineering and paleohydrological reconstruction. A major limiting factor in the study of large coarse materials is the difficulty of examining the entrainment and transport in flumes. Not surprisingly, there are very few studies on direct measurement of boulder transport in natural rivers.

The variety of controlled conditions in flume experiments cannot be determined in a natural river. Furthermore, the transport of several tons of megaboulders is not feasible in flume experiments. The 
variability in discharge of natural river systems can be investigated in these systems. Bedload moves sporadically and randomly on the river bed and is highly variable in short periods of time (Leopold and Emmett, 1976).

The stream power approach has been widely discussed in fluvial dynamics and may be a useful method in ungagged rivers during extreme flash floods (Parker et al., 2014; Knighton, 1999; Magilligan, 1992; Bagnold, 1986; Inbar and Schick, 1979).

The study of natural hazards may influence decisions regarding land use as well as the suitability of infrastructure and building codes in river floodplains. Evidence of boulder deposits in alluvial fans is a significant signature of the recurring periods of catastrophic floods (Inbar, 2000).

The rivers of Northwest Argentina belong to the group of torrential rivers with headwaters in mountain areas. The Sub-Andean basins are affected by strong rainfall in the summer causing flash floods with substantial damage to urban centers and transport infrastructure (Latrubesse and Brea, 2010). A wellstudied catastrophic flash flood in 1996 on the alluvial cone of Biescas (Spain) resulted in 85 casualties, mostly children who were spending their vacation at a summer camp (White et al., 1997).

The village of El Rodeo in the province of Catamarca developed on the alluvial river fan and the catastrophic flood of the Ambato river in January 2014 resulted in 13 casualties, destroyed several houses, a bridge and carried vehicles caught by the flood. Boulders of all sizes, including $2000 \mathrm{~mm}$ b-axis- of bed material were transported by the stream current. Several studies (Esper Angillieri et al., 2017; Eremchuk, 2015), and technical reports (Bravo, 2014) were published on the flood. The rainfall and flooding records allow the calculation of a recurrence interval of more than a hundred years for the exceptional catastrophic flood of January 2014.

The aims of this paper are: (a) To study the geomorphic and anthropic impact of the extreme flood in the river basin; (b) To evaluate the hydrological and sedimentological values, the planimetric cover of the channel terraces and alluvial fan altered by the flood; (c) To analyze the relationship between the Ambato river flood and megaboulder transport.

\section{GEOGRAPHICAL SETTING}

The village of El Rodeo is built on a tectonic depression between the mountains of Ambato and Colorado, at an altitude of $1300 \mathrm{~m}$ (Fig. 1). 
Fig. 1 Location map of the Ambato river in the province of Catamarca, Argentina.

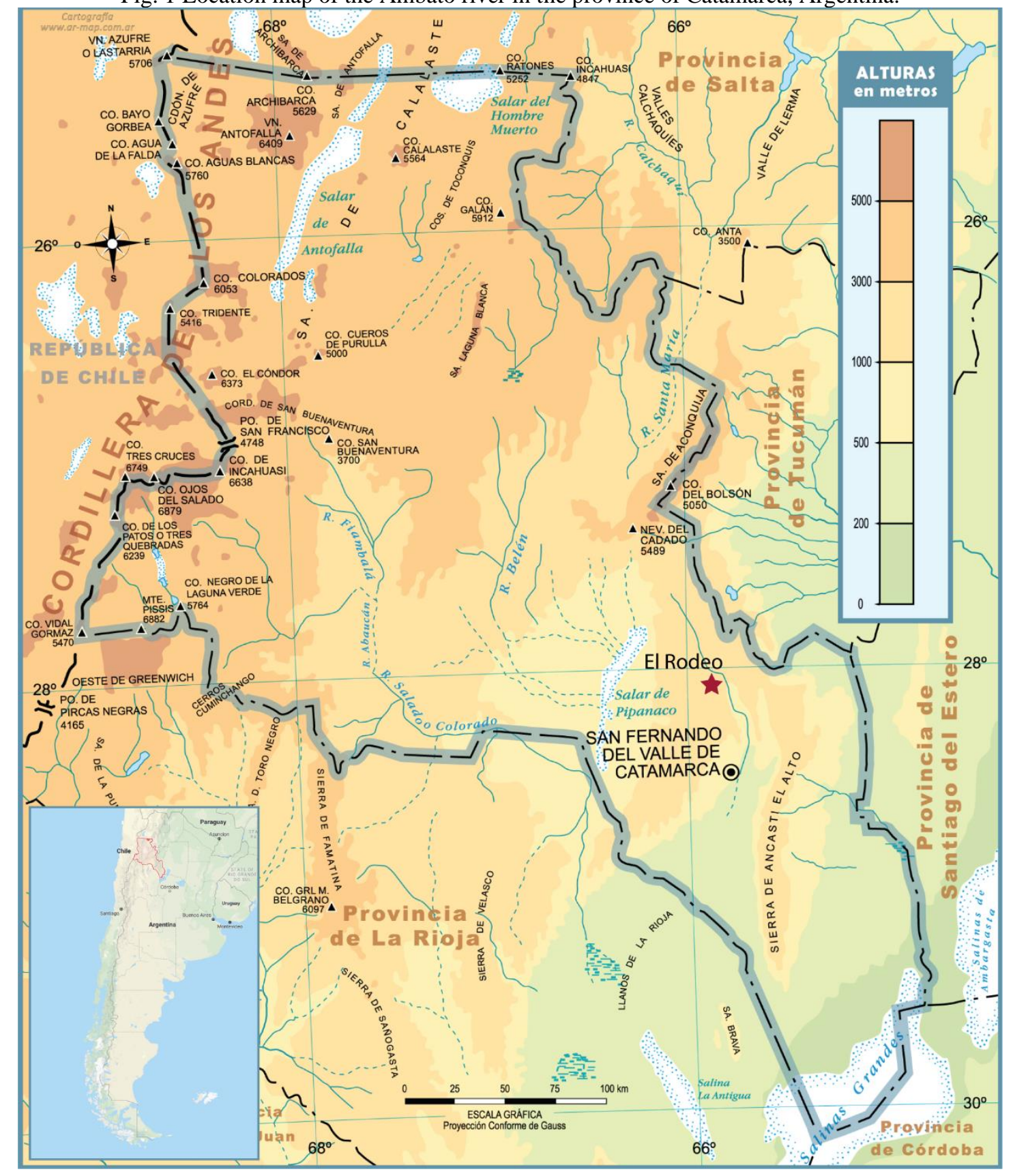

Two rivers drain into the El Rodeo valley in wide alluvial fans. The main channel is the Ambato river, originating in the mountains at an altitude of about $4500 \mathrm{~m}$ with a drainage basin area of $140 \mathrm{sq} \mathrm{km}$. The channel runs from the divide to the village area, its average slope, based on the $3200 \mathrm{~m}$ difference from the $4500 \mathrm{~m}$ divide to the $1300 \mathrm{~m}$ altitude of El Rodeo, is 0.08 or $8 \%$, for the total channel length of 40 km (Fig. 2). 


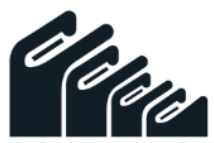

Fig. 2 The Ambato river channel, upstream of El Rodeo village

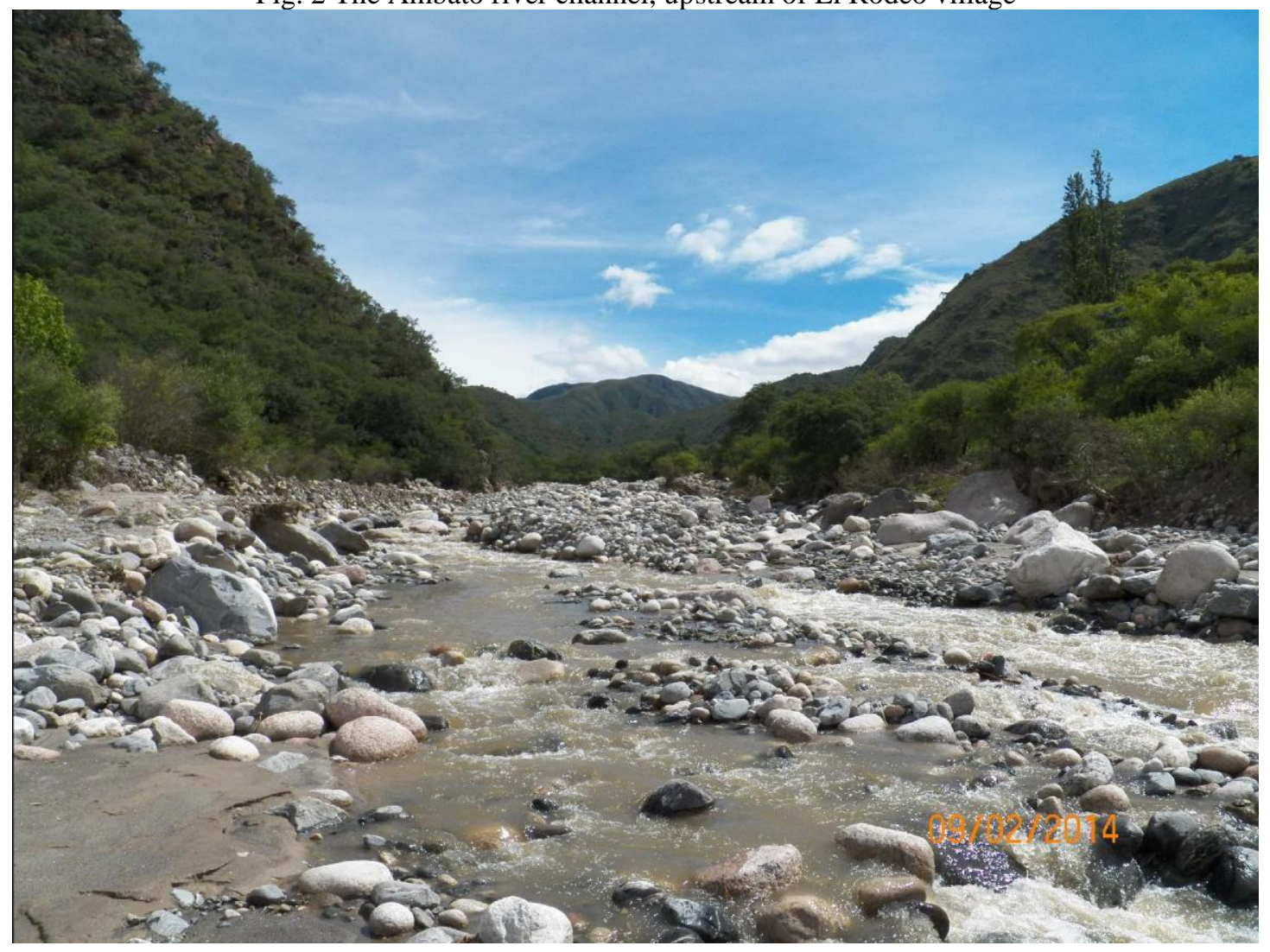

Except for the upper part, the Ambato river drainage basin lithology of Paleozoic age is covered by a mantle of loess. The fluvial system follows the main tectonic lines. The bedload material originates from the upper basin and from paleoterraces bordering the active channel. Several meters of colluvial deposits are at the apex of the paleo Ambato fan. The tectonic lateral ridges are the main orographic features of the region (Gonzalez Bonorino, 1978).

The village of El Rodeo is $38 \mathrm{~km}$ from the provincial capital, San Fernando de Catamarca, and is a tourist site with many "second/holiday homes". The total permanent population is several thousand people.

\section{CLIMATE}

Northwest Argentina has a semi-arid character. The mean annual precipitation at El Rodeo was $647 \mathrm{~mm}$ for the 1981-1999 period. In the Catamarca capital, at an altitude of $700 \mathrm{~m}$, the mean annual rainfall was $386 \mathrm{~mm}$ for the 1994-2016 period. $87 \%$ of the total annual rainfall occurs in the summer months from October to March (Palmieri et al, 2005). Southeast winds carrying moisture are the source of the precipitation in the summer months. Most extreme events are connected to El Nino years. 
Rainfall data are sporadic and available for the capital's airport and several village stations. In the village of El Rodeo, daily rainfall data were collected from 1981 to 1999 (Fig. 3). 1999 was the rainiest year with a total of $1,034 \mathrm{~mm}$.

Fig. 3 Yearly rainfall in El Rodeo: 1981-1999

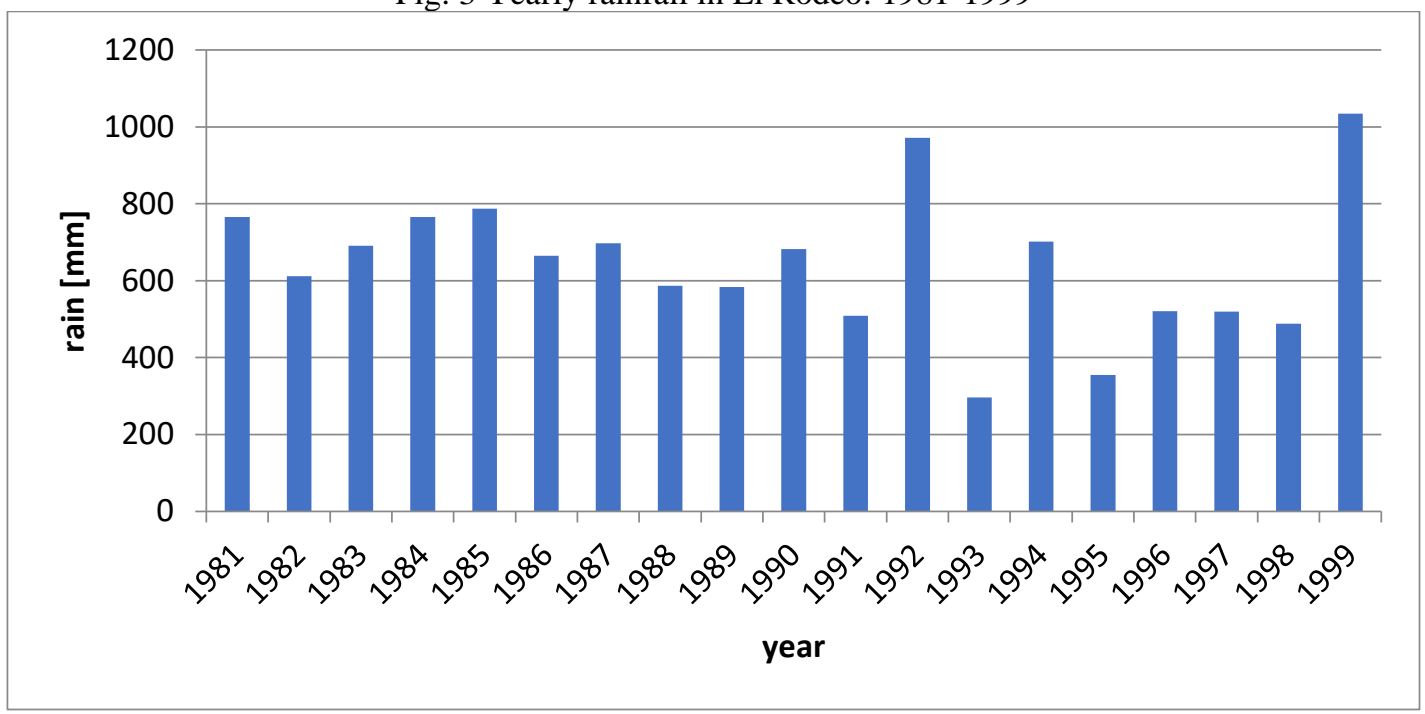

\section{THE FLOOD OF JANUARY 23, 2014}

There are no direct rainfall measurements in El Rodeo for the event of January 2014. At the Catamarca airport, about $70 \mathrm{~km}$ south of El Rodeo, the total rainfall was $10 \mathrm{~mm}$; and in the village of Las Juntas, $30 \mathrm{~km}$ to the north, $54 \mathrm{~mm}$ of rainfall were measured.

The flood originated from a short and sudden heavy rainstorm in the upper mountain. Analysis of satellite views indicated that the storm started on January 23 at 16:30 and ended at 22:00.

There are no measurements from extreme floods for the Ambato river or other rivers in the region. Anthropic factors influence the role of extreme floods in an urban environment, affecting the accuracy of the data. There are certain estimates that compensate for this lack of information, and calculations were made based on post-flood occurrence data and the relationship between water discharge and sediment transport.

The catastrophic flood of the Ambato river started on January 23, 2014 at 23:00 p.m. and continued for five hours until 4:00 on January 24. During the short peak of about 30 minutes after 23:00, the megablocks were transported and the camping bridge collapsed but its remains were not transported downstream (Bravo, 2014). The peak of the stream was recorded on video during the flood peak.

The total water flow discharge was $\sim 4 \mathrm{MCM}$ with a peak of $400 \mathrm{~m}^{3} / \mathrm{sec}$ to $600 \mathrm{~m}^{3} / \mathrm{sec}$ based on floodmarks and application of the Manning equation at several transversal channel cross-section surveys 
Fig. 4 High flood-marks of the January 2014 flood in the camping area of El Rodeo.

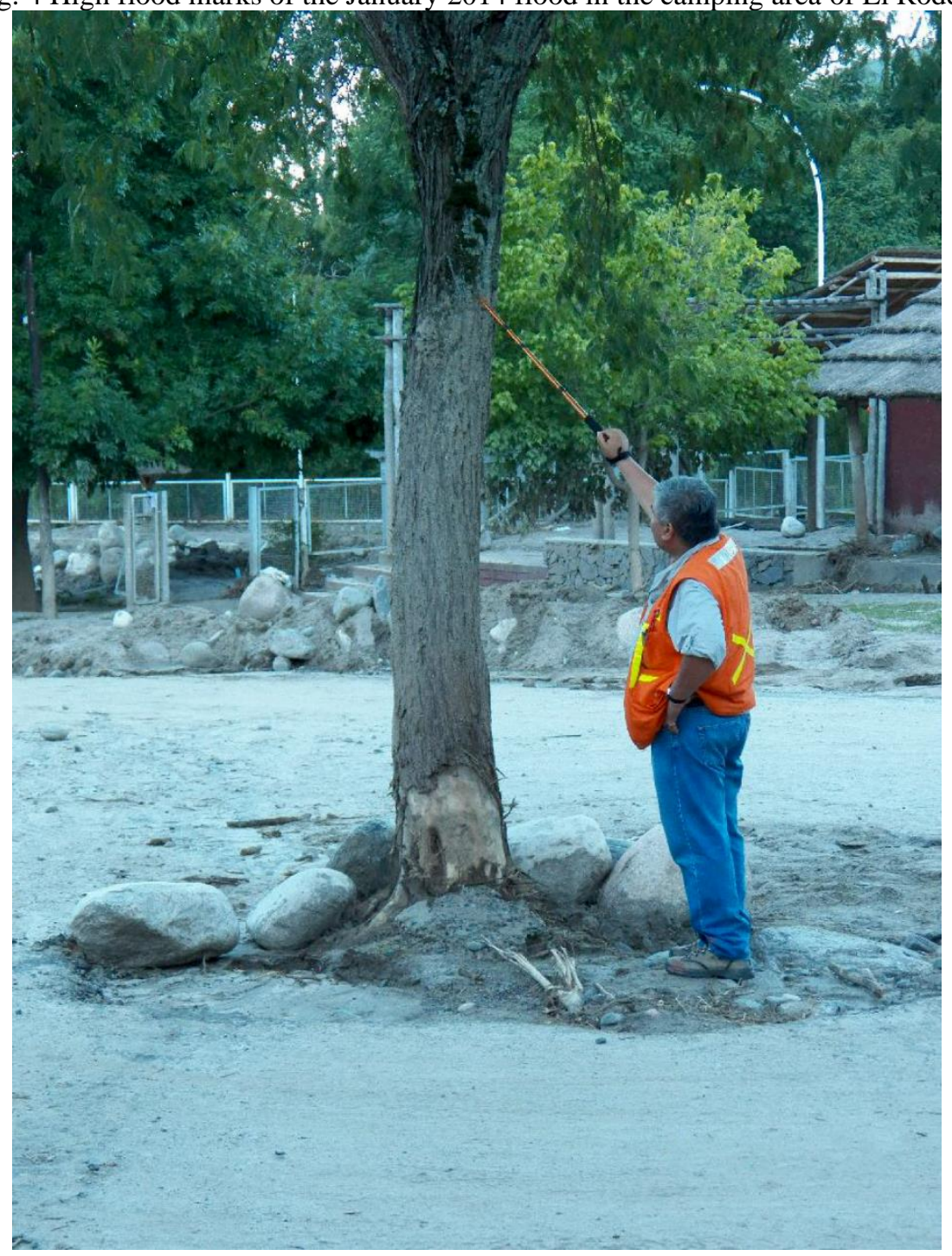

The flooding event of January 2014 was recorded as the largest in El Rodeo since the establishment of the village, about two hundred years ago. The rain cell was over the high mountain region of the basin, with an estimated $140 \mathrm{~mm}$ falling in a few hours. The estimated runoff/rainfall relationship was $20 \%$. Based on field evidence, the peak discharge in the 2014 event was ten times greater than the event of 1999, and therefore it may be considered an exceptional low frequency flood.

The flood covered several streets of the village with mud, restricting the mobility of cars until the early hours of the following morning. Local witnesses reported that the flood tapered off after 
approximately five hours. The estimated discharge rate at 9:00 a.m. on January 24 was $10 \mathrm{~m}^{3} / \mathrm{sec}$ according to one of the authors.

There was no evidence of extreme discharge values in the nearby Nogales river, indicating that the storm was concentrated in the Ambato river basin.

Maximum flow discharge was estimated using the Manning equation. Other estimates based on HEC hydrological models were of the same order of magnitude. The lowest estimate was of a maximum discharge of only $100 \mathrm{~m}^{3} / \mathrm{sec}$ (SEGEMAR, 2014).

A previous major flood affected the village in 1999, and a detailed channel survey was conducted by the authors in 2000. The estimated maximum discharge was $60 \mathrm{~m}^{3} / \mathrm{sec}$ based on floodmarks. Several cross sections were performed. No major damage was reported in 1999 but the authorities decided to remove boulders and increase the depth of the active channel (Fig. 5).

Fig. 5 Ambato river channel cross section (January 2000)

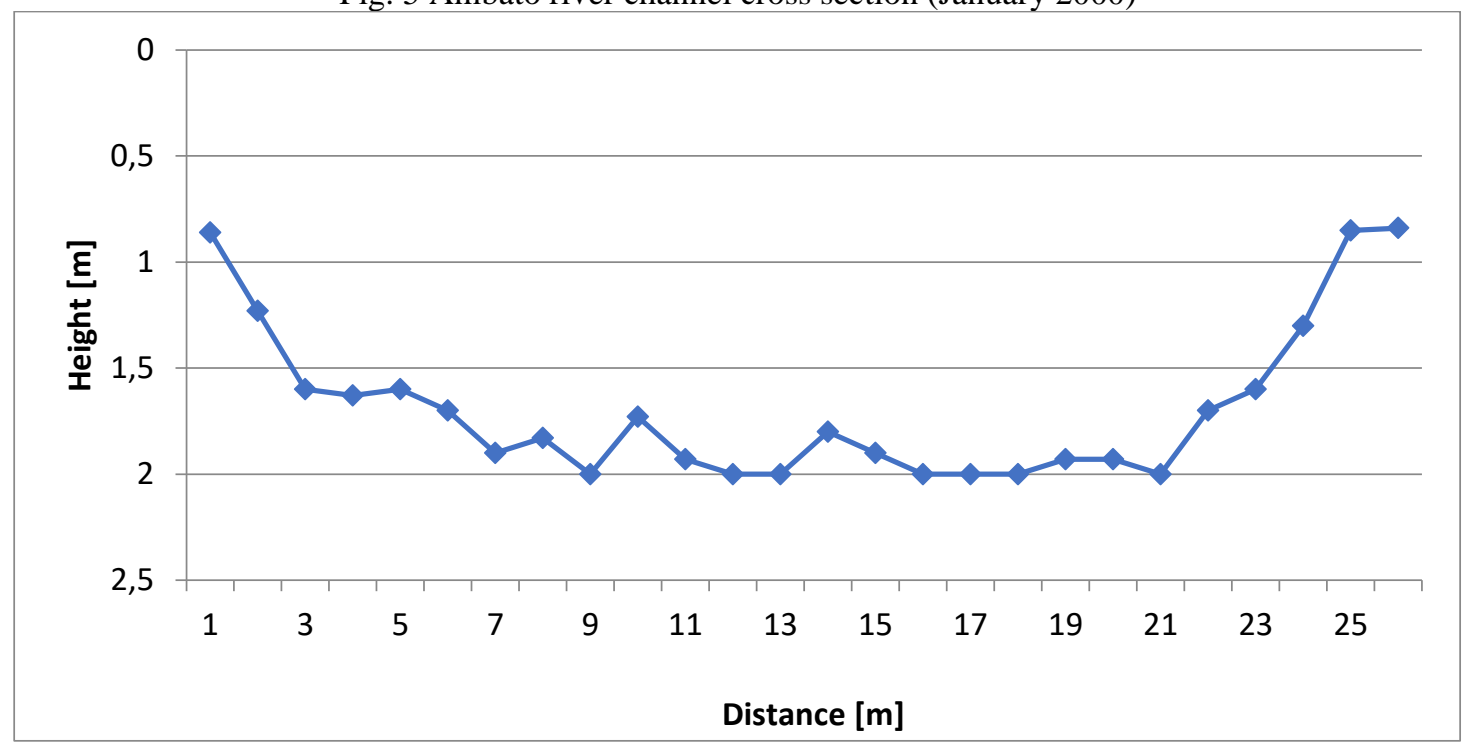

\section{GRANULOMETRY}

Bedload in the active channel is composed of granite, gneiss gravels and boulders. The megaboulders, with a median size greater than $1 \mathrm{~m}$, only move in extreme floods with high stream power. Megaboulders have been found in channel areas with slopes exceeding $2 \%$.

A detailed survey of the megaboulders was conducted during fieldwork in September 2016. Megaboulders with a median diameter- $b$ axis- of $1000 \mathrm{~mm}$ were deposited in the Ambato channel, before the junction of the three main streams draining the village (Fig. 6). Further down, the average slope decreases from $4 \%$ to $2 \%$ and no megaboulders have been found. These values are consistent with findings from other mountainous rivers (Baker and Costa, 1987; Inbar, 2000). It is assumed that during peak flow the water energy surface slope was above 0.04 thereby increasing stream power values. 


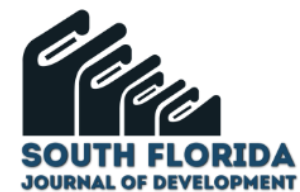

Fig. 6 Size distribution of coarse material and boulders in the Ambato river channel

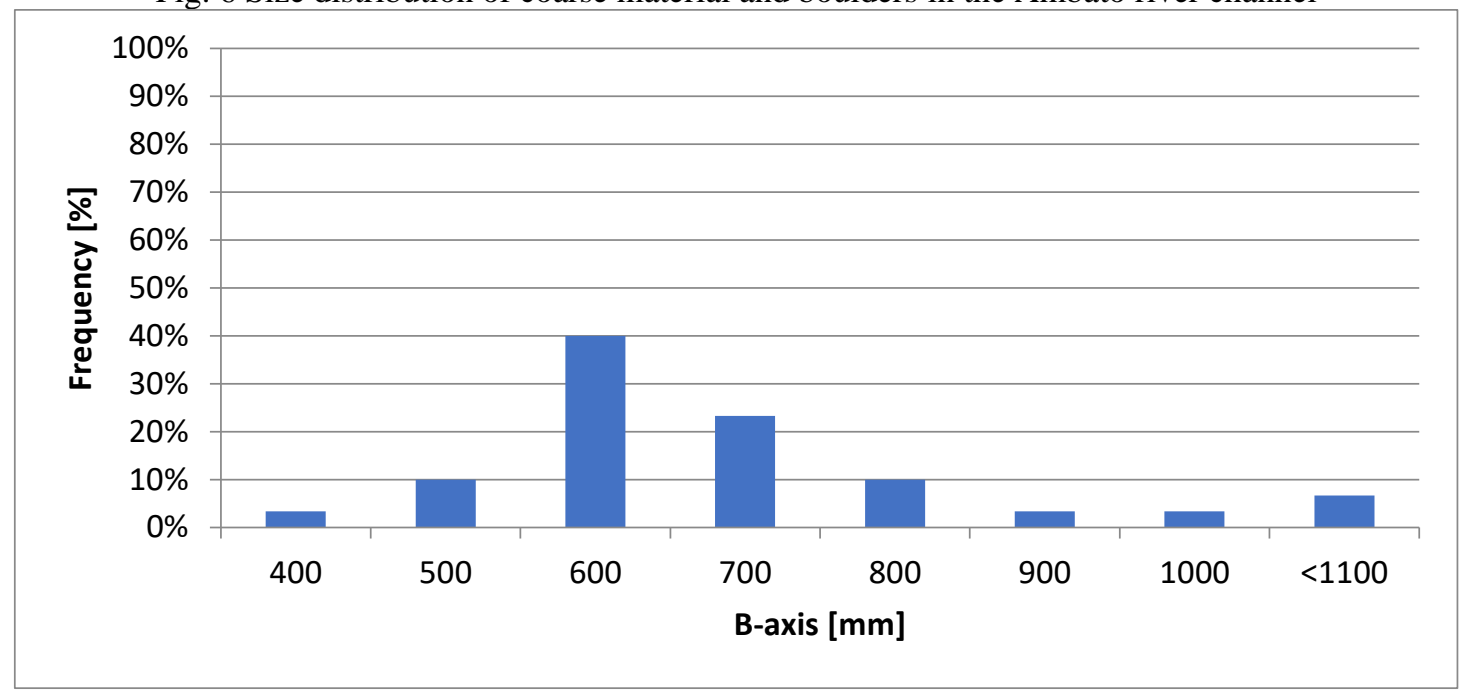

The validity of any general relationship between the transport rate to unit stream power is contingent upon the availability of an adequate amount of detritus in the channel, as found in the early field work done by the authors, forming a supply of material that is released during the flood. The bedload actually transported during the high flow is rather well represented by the bed material measured after the flood (Fig. 7).

Fig. 7 Coarse gravels and boulders deposited in a bar structure after the flood.

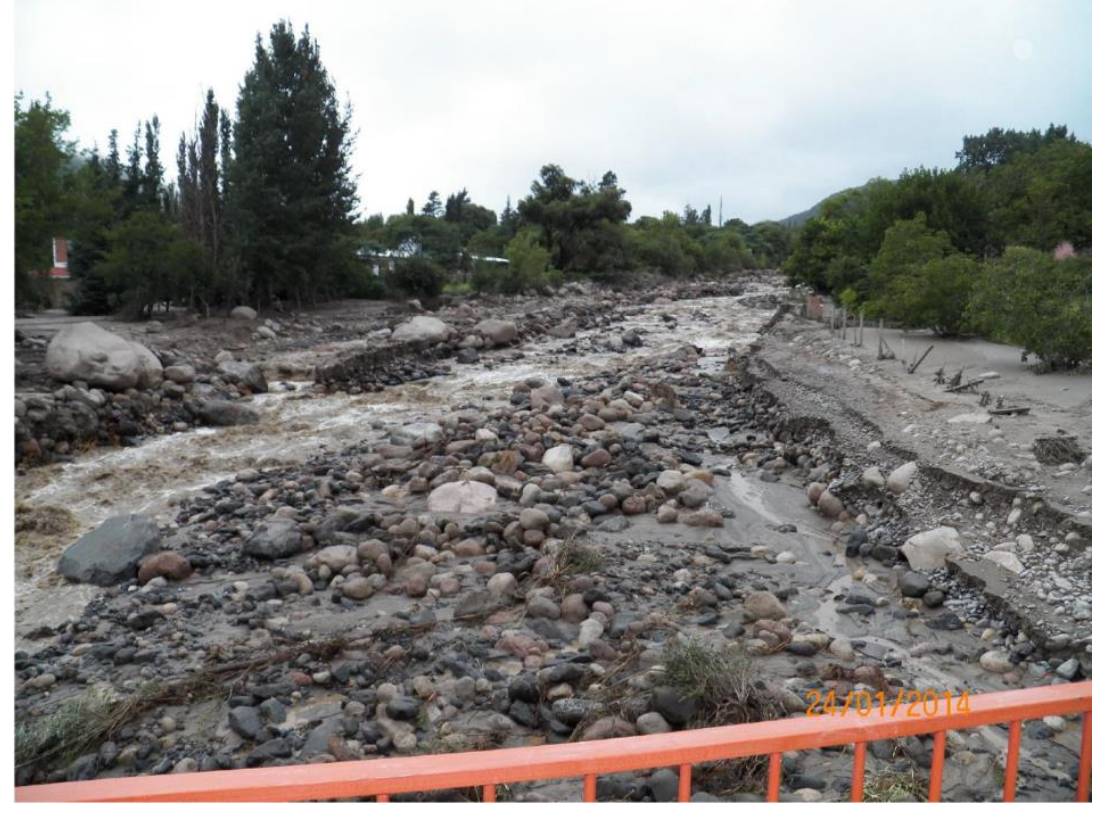

\section{STREAM POWER}

Particles as bedload transport may glide, roll or jump but close to the bed their displacement is intermittent (Graf, 1998). We used the empirical equation described by Leopold and Emmett (1976) for 
small and median sizes and by Inbar (2005) for megaboulders. The theoretical basis for these empirical equations was given by Bagnold in 1966.

The relation of stream power to bedload transport has been investigated in a few field studies. The movement of coarse material correlates with power expenditure of the flowing water as suggested by Bagnold. The dependent variable is the bedload transport rate, ib, in kilograms per meter of channel width per second. The independent variable is stream power per unit width of channel, $\grave{\omega}$, in kilograms per meter of width per second. Regarding megaboulder transport, the equation indicates the order of magnitude of the bedload transported (Dunne and Leopold, 1978)

Fig. 8 Empirical equation of bedload discharge against stream power (Modified after Leopold and Emmett, 1976, Inbar, 2005)

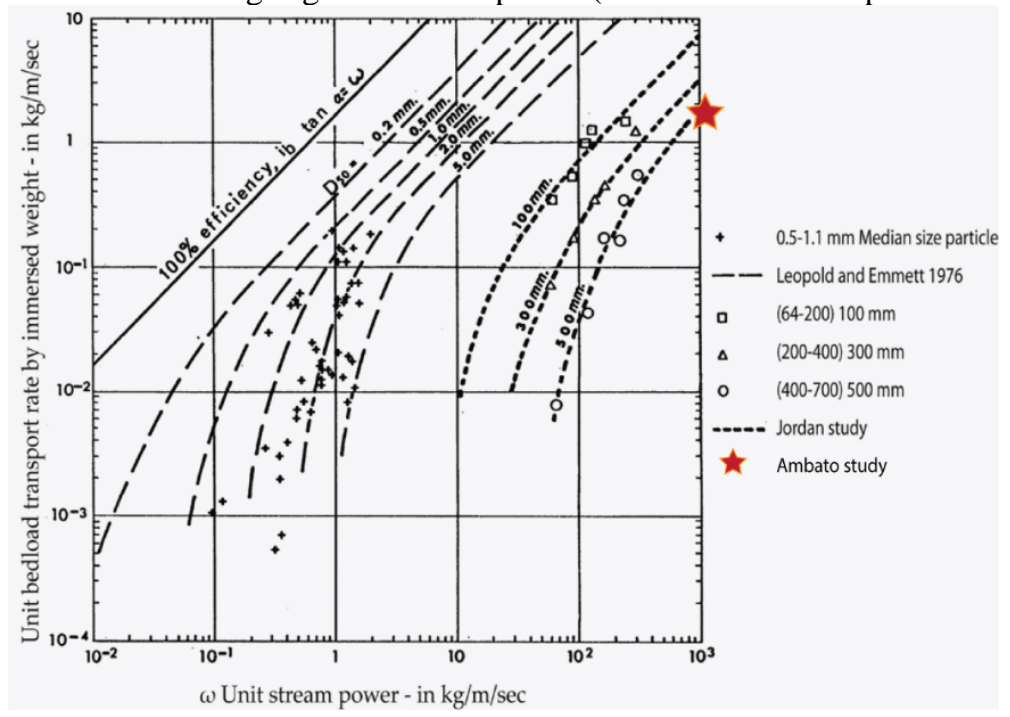

We applied the empirical theory for boulder mobility, developed for the Jordan river in Israel (Inbar and Schick, 1979). The obtained stream power value for a stream discharge of $400 \mathrm{~m}^{3} / \mathrm{sec}$ was 333 $\mathrm{kg} / \mathrm{m} / \mathrm{sec}$. The empirical value shown in figure 8 gives a sediment discharge for the dominant debris size of $\sim 3 \mathrm{~kg} / \mathrm{m} / \mathrm{sec}$. For a total flood width of $60 \mathrm{~m}$ and a period of 5 hours, the total boulder discharge is 33,000 tons or about 3,000 to 4,000 boulders. The results of a field survey of the fresh sediment deposited in the channel were similar to those obtained by the empirical equation (Fig. 8). 


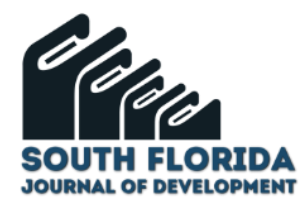

Fig. 9 Junction of the Nogales, Ambato and Seco channels draining the alluvial fan (Google Earth)

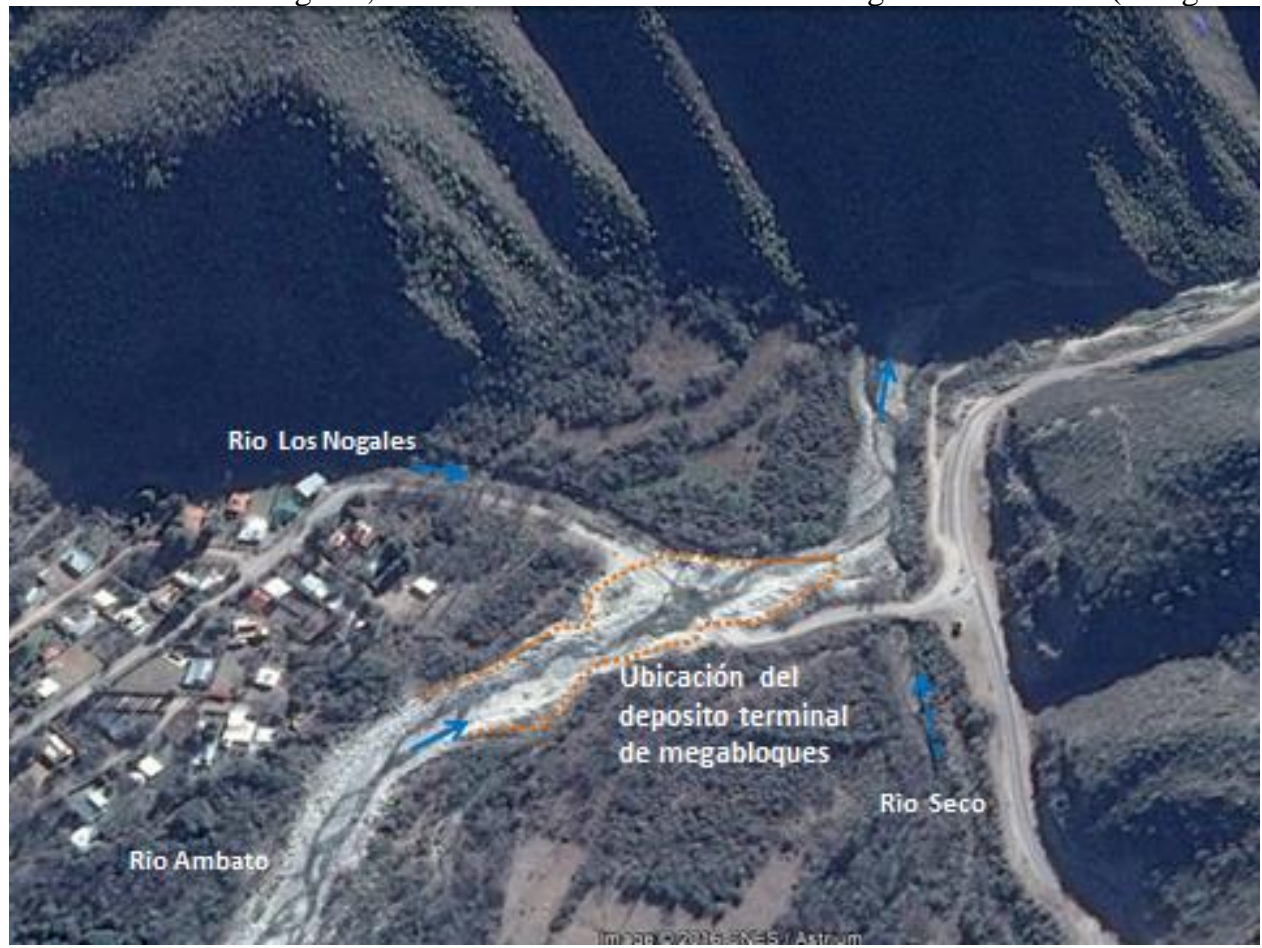

Data from field measurements of the movement of boulders above $500 \mathrm{~mm}$ - $\mathrm{b}$ axis- agree with calculated values from the bedload transport rate/unit stream power ratio established by the empirical equation for particles 0.5- $2 \mathrm{~mm}$ and were also valid for boulder size bedload movement (Bagnold, 1986; Inbar, 2000) (Fig. 10).

Figs.10- a,b big boulders deposited in the alluvial fan destroying buildings.

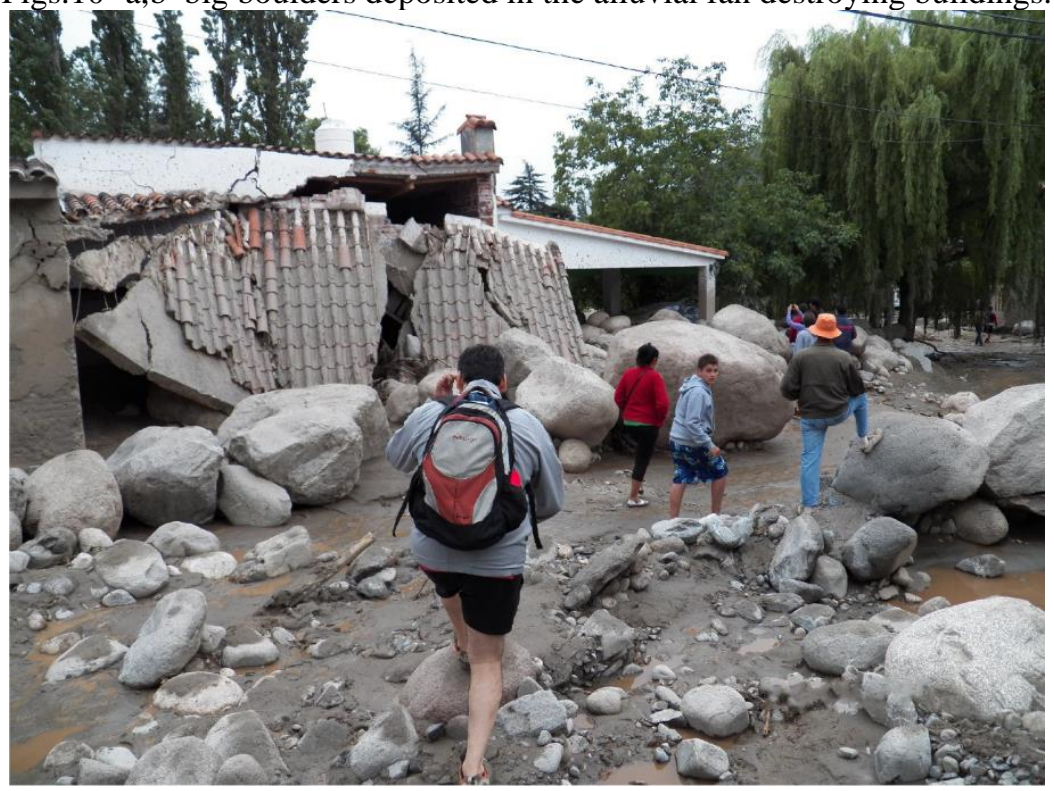




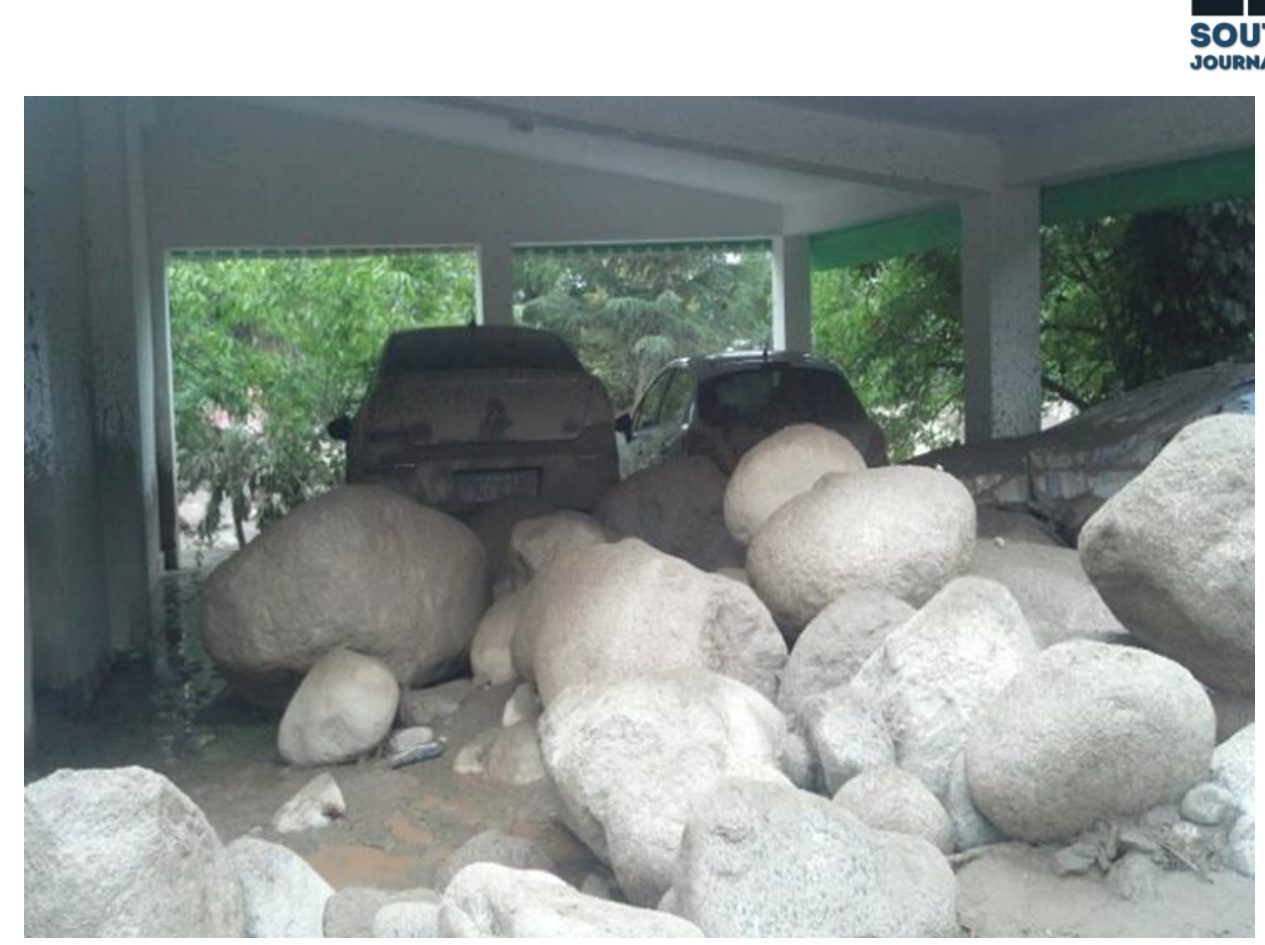

Fig. 11 Boulders deposited in houses built on the alluvial plain.

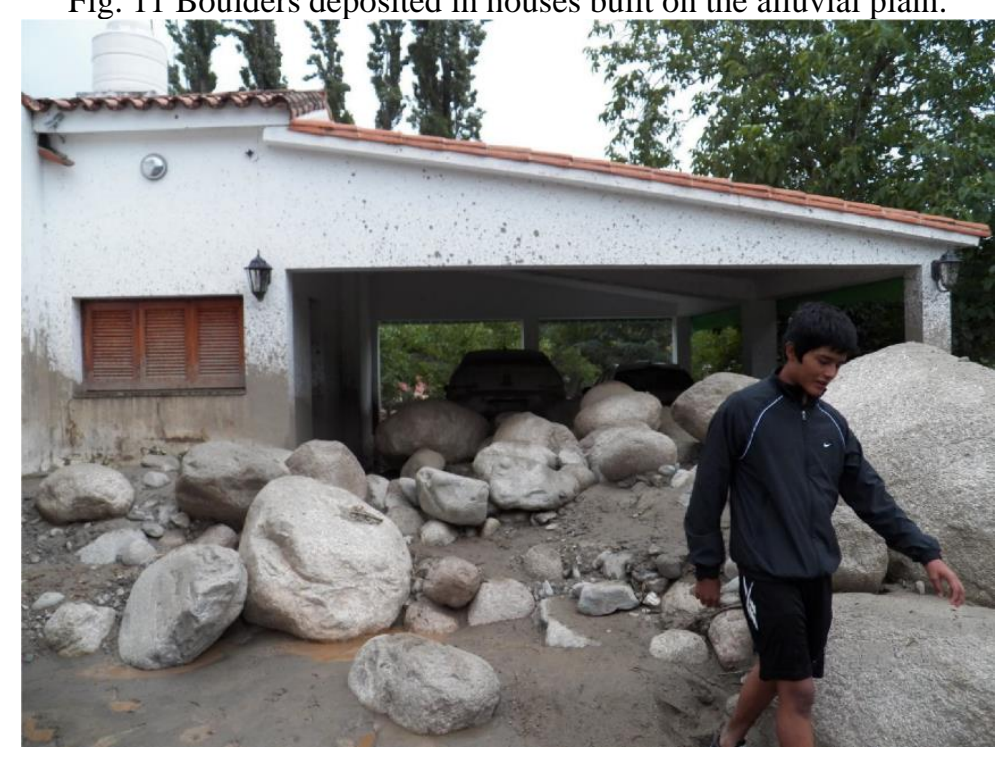

\section{MORPHOLOGICAL EFFECTS OF THE FLOOD}

The key morphological effects of a flood on the fluvial system depend on: (1) the local physiographic conditions, and (2) the size of the particles transported. The main areas affected by the flood were the flood plain adjacent to the river and several paleo-channels flowing into the village (Eremchuk, 2014) (Fig. 12).

Transversal cross-sections were made in the field studies (Bravo, 2014). The active channel is about $20 \mathrm{~m}$ wide and at the annual flood 1-1.5 m deep. The active floodplain is about $10 \mathrm{~m}$ wide on each river bank comprised of coarse sediment. The upper part is a river terrace covered by fine shallow sediments and wild vegetation or planted trees. The extreme catastrophic flood covered the upper terrace as well as the dry channels incised into them. 


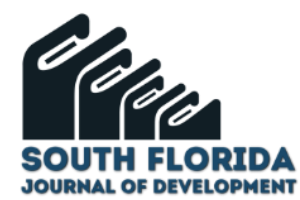

The village is built on an alluvial cone with a typical braided system for channels, some of them were not active (defined as paleo-channels), and were reactivated by the flood. No major incision was observed and most erosion features were on the banks and floodplains.

Fig. 12 frequently flooded areas in the river floodplain. 1. Frequently flooded areas. 2. Areas flooded by 1:50 year floods. 3. Areas susceptible to occasional floods. 4. Areas susceptible to exceptional floods (modified after Eremchuk, 2015).

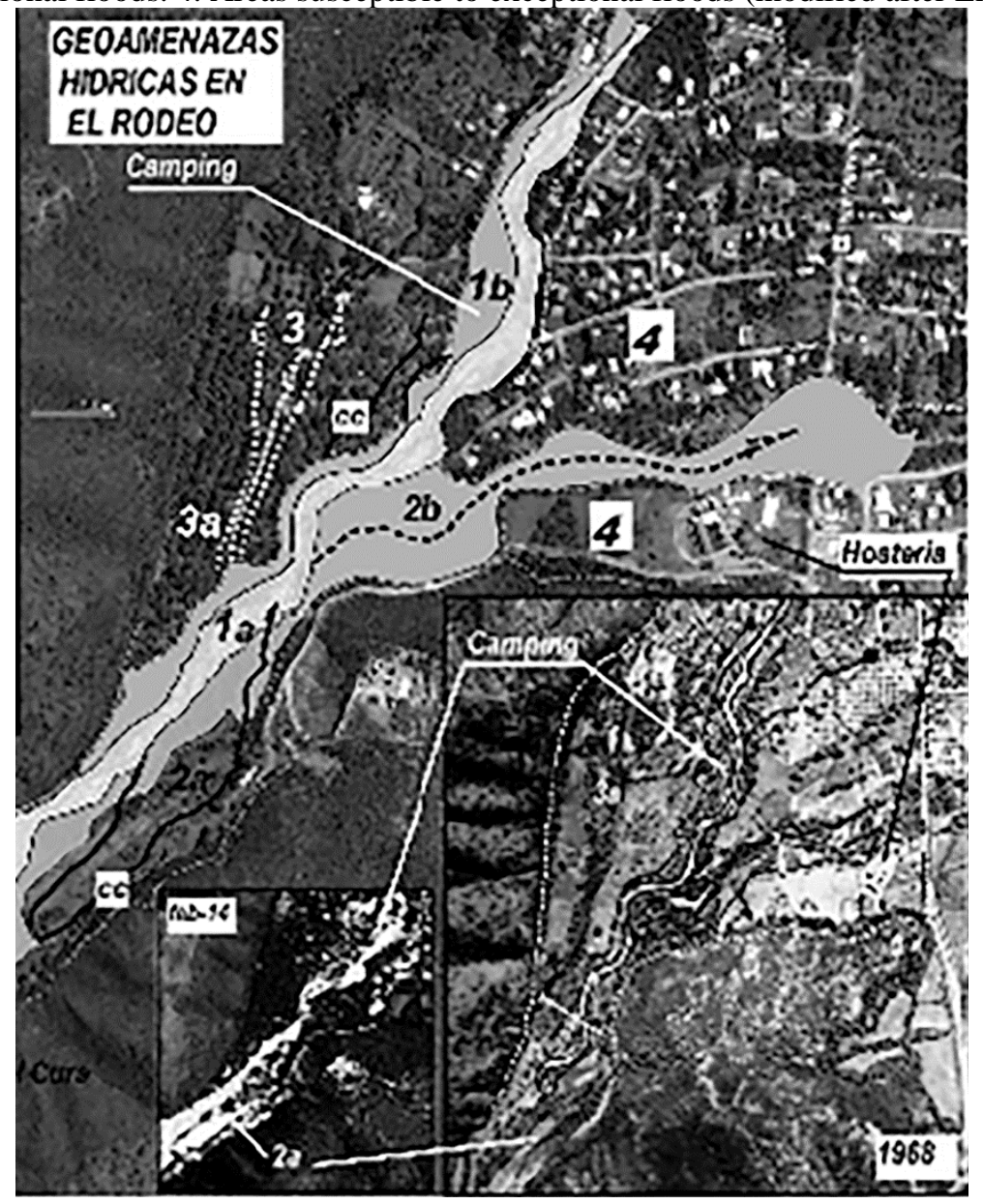

\section{RECURRENCE INTERVAL OF THE 2014 FLOOD}

There is no hydrological record and daily rain measurements are only available from the last 20 years, therefore an accurate recurrence interval for the flood (Fig. 3) cannot be defined. One estimate, based on hydrological models, gave an order of 400 to 600 years. Assuming a peak discharge of 450 $\mathrm{m}^{3} / \mathrm{sec}$, the recurrence interval is 1:200 years. Another estimate based on satellite images during past floods, showing flooded areas, gave the 2014 flood a recurrence interval of 75 to 100 years (Eremchuk, 2015) (Fig. 12). A preliminary estimation based on flood marks upstream of the camping site gives a recurrence interval of 100 years (SEGEMAR, 2014).

Local inhabitants had not witnessed a flood of similar magnitude in the last fifty years, and there are no reports of a similar incident in the last 100 years. The morphological effects of the flood in 1999 
were studied by the authors, giving an estimated peak discharge of $60 \mathrm{~m}^{3} / \mathrm{sec}$ for the Ambato river and 50 $\mathrm{m}^{3} / \mathrm{sec}$ for the Nogales river. 1999 was the rainiest year in the 20 year interval between 1980-2000, with a total of $708 \mathrm{~mm}$ for the summer 1998-1999 and $210 \mathrm{~mm}$ for March 1999. The 1999 flood originated after a rainfall of $160 \mathrm{~mm}$. The recurrence interval of the March 1999 flood was estimated at 1:50 years; partially based on testimonies from inhabitants given in 2000 .

Due to the fact that no major flood was detected in the neighboring Rio Nogales, the origins of the 2014 flood were a concentrated rainfall in the upper basin of Rio Ambato. Therefore, based on geomorphological and hydrological data we suggest that the recurrence interval for the Rio Ambato flood of January 2014 is at least 1:100 years.

\section{VICTIMS AND DAMAGE OF THE FLOOD}

One bridge, several houses and vehicles were totally destroyed (Figs. 13a-13b). The main road and a number of other village roads were severely affected. The total cost of the damage was estimated as one to two million dollars. Most of the properties were not insured and no clear estimate of the direct damage of the flood has been made. The summer tourist season was badly affected (El Esquiu).

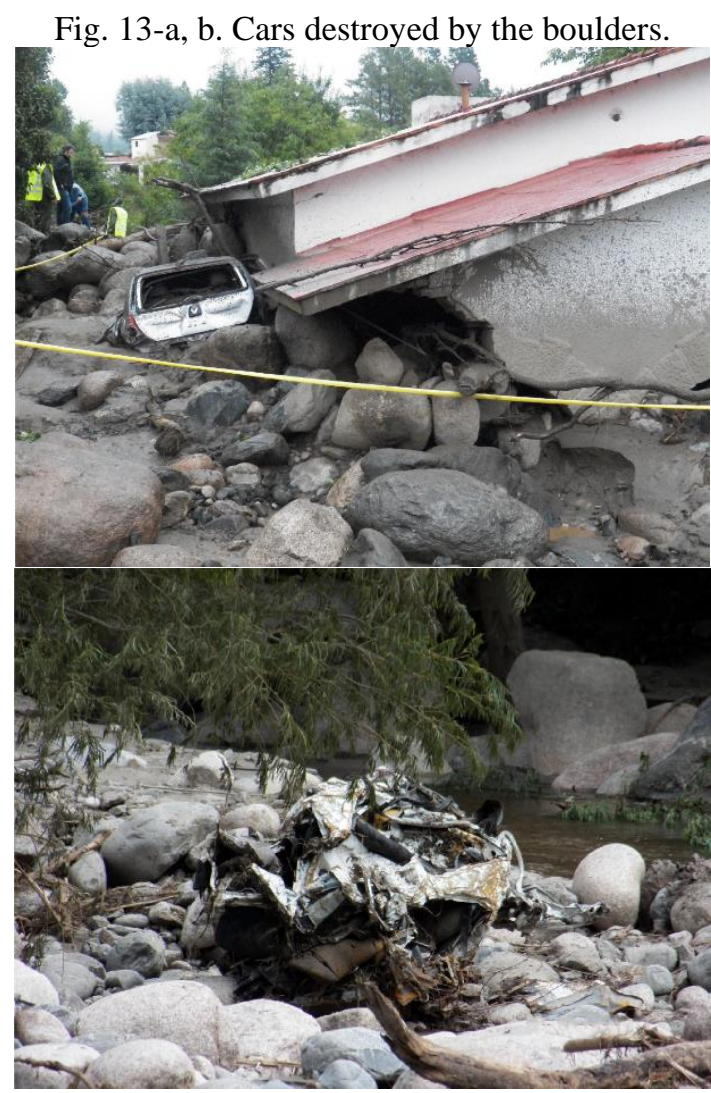




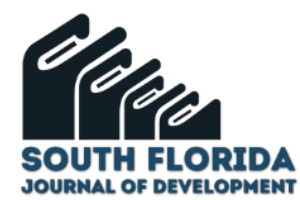

There were thirteen flood victims, most from the camp site that was completely destroyed. About 100 people were evacuated from their houses. 35 cars were severely damaged. Bridges and roads were reopened twelve hours after the flood, and it took about ten days for services to be fully reestablished and for life to return to normal.

Recovery work included planning and rehabilitation of the infrastructure, mainly the affected bridges and roads. Several proposals to reduce potential future disasters, were submitted to the local, provincial and central authorities. More than five years have passed since the event and none of the projects have been implemented.

\section{CONCLUSIONS}

The geomorphological signature of natural hazards in general, and flood events in particular are important to analyze. By examining the factors involved prediction of future floods may be possible, as may decisions regarding land use and infrastructure planning. The alluvial plain must be considered as an integral part of river dynamics (Fig. 14).

Based on morphological and historical evidence the recurrence interval of the 2014 Ambato flood is 1:100 years. Large exceptional floods like the Ambato river flood, exceed the channel erosional threshold causing changes in channel morphology (Wohl, 2001). The assessment of boulder mobility is needed for the mitigation of flow hazards in mountainous urban areas.

Fig. 14. Aerial view of the alluvial fan showing built areas in the floodplain damaged by the flood (El Esquiu newspaper, 25 January 2014)

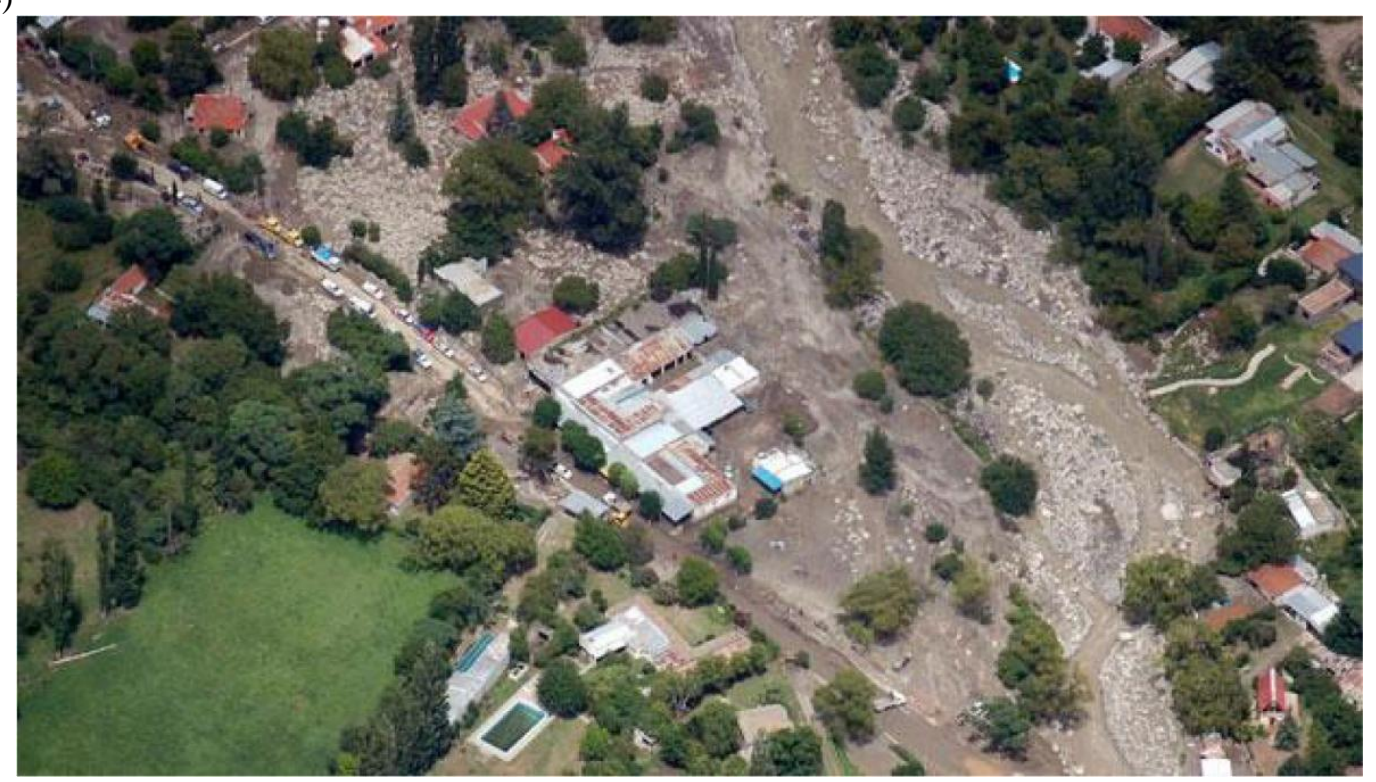

The empirical equation for stream power values and the transport of megaboulders was proved as valid for the Ambato flood and this is probably one of few studies of megaboulders transported by a flood. 
The equation is not meant to be an engineering tool for design, but an indication of the order of magnitude of boulder transport that agrees with the field measurements. Flood control structures in the upper basin are expensive and they may not be able to minimize downstream flood damage.

The effects of climate change in semi-arid environments would be greater if they included increased precipitation or more extreme rainstorms due to events such as El Niño. 


\section{REFERENCES}

Bagnold RA (1966): An approach to the sediment transport problem from general physics. USGS Prof. Paper 422-I, 37 pp.

Bagnold RA (1986): Transport of solids by natural water flow: evidence for a worldwide correlation. Royal Society of London Proceedings, A. v. 372, 453-473.

Baker VH, \& Costa E (1987): Flood power. In: Catastrophic Flooding. Edited by L.Mayer \& D.Nash. 121. Allen \& Unwin, London, UK.

Bravo C (2014): Aluvion del Rio Ambato en El Rodeo, Propuestas. 36pp.

Dunne, TH., \& Leopold LB (1978): Water in Environmental Planning. W.H. Freeman and Co. San Francisco, 818 pp.

El Esquiu Newspaper, 25 January, 2014

Eremchuk J (2015): Evidencias geologicas y geoamenazas hidricas en la villa El Rodeo, Dpto. Ambato, Catamarca, Produccion cientifica de la Facultad de Tecnologia y Ciencias Aplicadas, 73-82.

Esper Angillieri MY, Perucca, L, Vargas, N (2017): Catastrophic flood triggered by an extreme rainfall event in El Rodeo village, January 2014, Northwestern Pampean Ranges of Argentina. Geografiska Annaler, v. 99, 72-84.

Gonzalez Bonorino F (1978): Descripcion Geologica de la Hoja 14f, San Fernando del Valle de Catamarca. Servicio Geologico Nacional, Boletin 160, 85 pp. Buenos Aires.

Graf WH (1998): Fluvial Hydraulics. John Wiley \& Sons, 681 pp.

Inbar M \& Schick AP (1979): Bedload transport associated with high stream power, Jordan River, Israel. Proc. of the National Academy of Sciences, USA, vol. 76, 6 2515-2517.

Inbar M (2000): Episodes of flashflood and boulder transport in the Upper Jordan river. IAHS Publication, $261,185-200$.

Inbar M (2005): Short-term channel changes after flash floods in the Upper Jordan river. Horizons in Geography, v. 64-65, 121-131 (Hebrew, with English abstract).

Knighton AD (1999): Downstream variations in stream power. Geomorphology, 29, 293-306.

Latrubesse EM \& Brea D (2010): Floods in Argentina. In: Natural Hazards and Human-Exacerbated Disasters in Latin America, EM Latrubesse (Ed.) Developments in Earth Surface Processes, 13, 333-378.

Leopold LB \& Emmett WW (1976): Bedload measurements, East Fork River, Wyoming. Proc. of the National Academy of Sciences, USA. vol.73, 4. 1000-1004.

Magilligan FJ (1992): Thresholds and the spatial variability of flood power during extreme floods, Geomorphology, 5, 373-390. 
Palmieri CN, Olmes LR, Quiroga A, De La Orden E, Carma MI. (2005): Caracterizacion Hidroclimatica de Siete Localidades del Departamento Ambato, Provincia de Catamarca. Cizas, v.6, 1 y 2, 7-17.

Parker CH, Thorne CR, Clifford, NJ (2014): Development of STREAM: a reached based stream power balance approach for predicting alluvial river channel adjustment. Earth Sciences Processes and Landforms, v. 40,3: 403-413.

SEGEMAR, 2014: Informe preliminar sobre los aluviones ocurridos el 23 de Enero 2014 en las ciudades catamarquenas de El Rodeo y Sijan. Buenos Aires, 2 pp.

White, S, Garcia Ruiz, JM, Marti, C, Valero B, Errea MP, Gomez Villar A, (1997): The Biescas campsite disaster in the Central Spanish Pyrenees and its temporal and spatial context. Hydrological. Processes, 11: $1797-1812$.

Wohl, E., 2007: Review of effects of large floods in resistant boundary channels. Development in Earth Surface Processes, v. 11, 211-212. 